\title{
Aetio-microbiologic profile of febrile children in a tertiary care hospital
}

\author{
Alexander Mannu', *Jaishree Vasudevan² \\ Sri Lanka Journal of Child Health, 2021; 50(4): 595-601 \\ DOI: http://doi.org/10.4038/sljch.v50i4.9844
}

\begin{abstract}
Objectives: To assess the culture-positive infection rate, profile of organisms and antibiotic sensitivity pattern of common culture isolates in various body fluids among children presenting with febrile illness to a tertiary care hospital.
\end{abstract}

Method: A retrospective study was carried out from January 2013 to December 2016 on children who presented with febrile illness for more than 3 days and had a culture taken of the relevant body fluid/ specimen/tissue, based on clinical profile.

Results: A total of 7683 children was included in study. Culture positive infection rate was $18.8 \%$ in the study population. Urinary tract infection (UTI) was the commonest infection occurring in 761 $(9.9 \%)$ children. Escherichia coli $($ E. coli) was the commonest isolate, being found in 431 (5.4\%) specimens. An intermediate pattern of sensitivity was observed for gentamycin and colistin. Most $E$ coli strains were sensitive to other antibiotics. Most Enterococcus species were resistant to cotrimoxazole, clindamycin, and cephalosporins. Almost half the strains indicated an intermediate sensitivity pattern to colistin and gentamycin.

Conclusions: Culture positive infection rate was $18.8 \%$ in the study population, UTI being the commonest infection and E.coli the commonest isolate.

(Key words: Febrile, Antibiotic, Escherichia coli, Enterococcus, Retrospective).

\section{Introduction}

Fever accounts for $10-25 \%$ of paediatric emergency

${ }^{1}$ Chettinad Hospital and Research Institute Kelambakkam, India, ${ }^{2}$ Tagore Medical College and Hospital, Chennai, India

*Correspondence: DrJaishree.vasu@gmail.com

https://orcid.org/0000-0002-1265-2802

(Received on 05 September 2020: Accepted after revision on 16 October 2020)

The authors declare that there are no conflicts of interest.

Personal funding was used for the project.

Open Access Article published under the Creative

Commons Attribution CC-BY@C (i) License department visits in low and middle-income countries $^{1,2}$. Though most febrile children have self-limited viral infections, a few will have serious bacterial infection $(\mathrm{SBI})^{3,4}$. Further, among febrile admissions, case fatality rates may exceed $20 \% \%^{5,6}$. SBI occurs in $6-10 \%$ of less than 3 -month-old infants and $5-7 \%$ of 3-36 month old children ${ }^{7,8}$. In a rural set-up where many children seek care due to some febrile illness, availability of laboratory investigations is limited and hence performing culture and sensitivity tests before standard medical treatment is very difficult, thereby relying on the overall bacteriological profile of similar illnesses reported in their urban counterparts where such tests are feasible and can be readily carried out.

\section{Objectives}

To assess the culture-positive infection rate, profile of organisms and antibiotic sensitivity pattern of common culture isolates in various body fluids among children presenting with febrile illness to a tertiary care hospital.

\section{Method}

A retrospective analysis was carried out in the paediatric out-patient and in-patient departments of a tertiary care teaching hospital in South India. Study population included all the children aged up to 17 years presenting with febrile illness to the study setting and had a culture of the relevant body fluid / specimen / tissue taken, based on clinical profile from January 2013 to December 2016. Children who did not undergo culture and sensitivity testing and children presenting with fever of obvious viral aetiology with lacrimation, rhinorrhoea or rash were excluded from the study.

Ethical issues: Approval for the study was obtained from the Institutional Human Ethics Committee of Chettinad Academy of Research and Education, Chennai, India (No. 104/A/IHEC/August 2020). Confidentiality of study participants was maintained throughout the study. Being a retrospective study, informed consent was not a possibility

Statistical analysis: Descriptive analysis was carried out by means and standard deviations. IBM SPSS version 22 was used for statistical analysis ${ }^{11}$.

\section{Results}

There was a total of 7683 children included in the study. The age and gender distribution of the study participants are shown in Table 1. 
Table 1: Age and gender distribution of study participants $(n=7683)$

\begin{tabular}{|l|l|}
\hline \multicolumn{1}{|c|}{ Parameter } & Number (\%) \\
\hline Age group (years) & \\
Less than 5 & $4973(64.7)$ \\
5 to 10 & $1264(16.5)$ \\
Above 10 & $1446(18.8)$ \\
\hline Sex & \\
Male & $4363(56.8)$ \\
Female & $3320(43.2)$ \\
\hline
\end{tabular}

Culture positive infection rate was $18.8 \%$ (95\% CI $17.96 \%$ to $19.71 \%$ ) among the study population. The incidence of culture positivity in various specimens in the study population is shown in Table 2.

Table 3 shows the age and gender distribution of culture-positive infections in the study population. Among all age groups, UTI was the most common infection. Among 0 to 5 year old children, bloodstream infection with culture positivity was the next common, whereas throat infection was the next common in 5 to 10 year old children and wound infection, the next common in the above 10 year old children. UTI was the most common infection in both boys and girls.

Table 2: Incidence of culture positivity in various specimens in study population

\begin{tabular}{|l|c|}
\hline \multicolumn{1}{|c|}{ Sample } & Number (\%) \\
\hline Negative & $6237(81.2)$ \\
\hline Positive & $1446(18.8)$ \\
Urine & $761(09.9)$ \\
Blood & $208(02.7)$ \\
Throat swab & $150(02.0)$ \\
Pus & $123(01.6)$ \\
Wound swab & $122(01.6)$ \\
Eye swab & $25(0.3)$ \\
Ear swab & $18(0.2)$ \\
Sputum & $14(0.2)$ \\
Others & $25(0.3)$ \\
\hline
\end{tabular}

Table 3: Age and gender distribution of culture-positive infections in the study population (n=7683)

\begin{tabular}{|l|c|c|c|c|c|}
\hline \multirow{2}{*}{ Sample } & \multicolumn{3}{|c|}{ Age Group } & \multicolumn{2}{c|}{ Gender } \\
\cline { 2 - 6 } & $\begin{array}{c}\mathbf{0 ~ t o ~ 5} \\
\mathbf{n}(\mathbf{\%})\end{array}$ & $\begin{array}{c}\mathbf{5} \text { to 10 } \\
\mathbf{n}(\mathbf{\%})\end{array}$ & $\begin{array}{c}\text { Above 10 } \\
\mathbf{n}(\mathbf{\%})\end{array}$ & $\begin{array}{c}\text { Female } \\
\mathbf{n}(\mathbf{\%})\end{array}$ & $\begin{array}{c}\text { Male } \\
\text { n (\%) }\end{array}$ \\
\hline Urine & $521(10.5)$ & $108(08.5)$ & $132(09.1)$ & $360(10.8)$ & $401(09.2)$ \\
\hline Blood & $157(03.2)$ & $25(02.0)$ & $26(01.8)$ & $92(02.8)$ & $116(02.7)$ \\
\hline Throat swab & $59(01.2)$ & $61(04.8)$ & $30(02.1)$ & $82(02.5)$ & $68(01.6)$ \\
\hline Pus & $75(01.5)$ & $16(01.3)$ & $32(02.2)$ & $44(01.3)$ & $79(01.8)$ \\
\hline Wound swab & $47(01.0)$ & $24(01.9)$ & $51(03.5)$ & $49(01.5)$ & $73(01.7)$ \\
\hline Eye swab & $25(0.5)$ & $0(0.0)$ & $0(0.0)$ & $10(0.3)$ & $15(0.3)$ \\
\hline Ear swab & $07(0.1)$ & $04(0.3)$ & $07(0.5)$ & $02(0.06)$ & $16(0.4)$ \\
\hline Sputum & $01(0.02)$ & $02(0.2)$ & $11(0.8)$ & $02(0.06)$ & $12(0.3)$ \\
\hline Others & $16(0.32)$ & $0(0.0)$ & $09(0.6)$ & $11(0.3)$ & $14(0.3)$ \\
\hline Culture negative & $4065(81.7)$ & $1024(81.0)$ & $1148(79.4)$ & $2668(80.36)$ & $3569(81.8)$ \\
\hline Total & $4973(100.0)$ & $1264(100.0)$ & $1446(100.0)$ & $3320(100.0)$ & $4363(100.0)$ \\
\hline
\end{tabular}

Table 4 shows the profile of organisms grown in all specimens. Escherichia coli was the most common isolate and Citrobacter species the least common isolate.

Table 4: Profile of organisms grown in all specimens

specimens
\begin{tabular}{|l|c|}
\hline \multicolumn{1}{|c|}{ Organism grown } & n (\%) \\
\hline Escherichia coli & $413(5.4)$ \\
\hline Enterococcus species & $137(1.8)$ \\
\hline Coagulase negative staphylococci & $132(1.7)$ \\
\hline Beta haemolytic streptococcus Gp. A & $131(1.7)$ \\
\hline Klebsiella species & $116(1.5)$ \\
\hline Staphylococcus aureus & $103(1.3)$ \\
\hline Acinetobacter species & $70(0.9)$ \\
\hline Pseudomonas aeruginosa & $42(0.6)$ \\
\hline Streptococcus species & $35(0.5)$ \\
\hline Proteus mirabilis & $35(0.5)$ \\
\hline Proteus vulgaris & $34(0.4)$ \\
\hline Pseudomonas species & $34(0.4)$ \\
\hline Salmonella typhi & $33(0.4)$ \\
\hline Citrobacter species & $26(0.3)$ \\
\hline Others & $94(1.2)$ \\
\hline
\end{tabular}

Table 5 shows the antibiotic sensitivity pattern of E.coli isolates. E. coli demonstrated maximum resistance to ampicillin and all generations of cephalosporins and macrolide group of antibiotics. The intermediate pattern of sensitivity was observed for gentamycin and colistin. The majority of the $E$. coli strains were sensitive to other antibiotics like linezolid, ceftazidime, netilmicin, chloramphenicol and tigecycline. (Table 5)

Table 6 shows the antibiotic sensitivity pattern of Enterococcus isolates in the study population. Analysis of the antibiotic sensitivity pattern of Enterococcus species showed that a major proportion of strains were resistant to cotrimoxazole, clindamycin, and various cephalosporins. Almost half of the strains showed an intermediate sensitivity pattern to colistin and gentamycin (Table 6). 
Table 5: Antibiotic sensitivity pattern of Escherichia coli isolates

\begin{tabular}{|c|c|c|c|}
\hline \multirow[t]{2}{*}{ Antibiotic } & \multicolumn{3}{|c|}{ Escherichia Coli } \\
\hline & Sensitive & Intermediate & Resistant \\
\hline Amikacin $(\mathrm{n}=408)$ & $96.8 \%$ & $0.74 \%$ & $2.45 \%$ \\
\hline Piperacillin-Tazobactam $(n=410)$ & $87.3 \%$ & $4.39 \%$ & $8.29 \%$ \\
\hline Nitrofurantoin $(\mathrm{n}=362)$ & $85.9 \%$ & $3.87 \%$ & $10.22 \%$ \\
\hline Gentamicin $(n=398)$ & $58.8 \%$ & $6.78 \%$ & $34.42 \%$ \\
\hline Imipenem $(\mathrm{n}=223)$ & $97.8 \%$ & $0.00 \%$ & $2.24 \%$ \\
\hline Meropenem $(n=215)$ & $93.0 \%$ & $0.93 \%$ & $6.05 \%$ \\
\hline Co-trimoxazole $(\mathrm{n}=408)$ & $33.6 \%$ & $0.00 \%$ & $66.42 \%$ \\
\hline Cefepime $(\mathrm{n}=409)$ & $32.3 \%$ & $2.69 \%$ & $65.04 \%$ \\
\hline Ciprofloxacin $(\mathrm{n}=409)$ & $30.8 \%$ & $0.73 \%$ & $68.46 \%$ \\
\hline Cefotaxime $(\mathrm{n}=402)$ & $28.9 \%$ & $0.75 \%$ & $70.40 \%$ \\
\hline Norfloxacin $(\mathrm{n}=351)$ & $29.9 \%$ & $1.71 \%$ & $68.38 \%$ \\
\hline Cefuroxime $(n=405)$ & $22.5 \%$ & $1.23 \%$ & $76.30 \%$ \\
\hline Cefazolin $(n=410)$ & $19.0 \%$ & $1.46 \%$ & $79.51 \%$ \\
\hline Tobramycin $(\mathrm{n}=40)$ & $82.5 \%$ & $7.50 \%$ & $10.00 \%$ \\
\hline Ampicillin $(n=400)$ & $8.0 \%$ & $0.50 \%$ & $91.50 \%$ \\
\hline Penicillin $(\mathrm{n}=27)$ & $70.4 \%$ & $0.00 \%$ & $29.63 \%$ \\
\hline Tetracycline $(n=26)$ & $61.5 \%$ & $0.00 \%$ & $38.46 \%$ \\
\hline Gentamicin $(n=42)$ & $38.1 \%$ & $50.00 \%$ & $11.90 \%$ \\
\hline Teicoplanin $(\mathrm{n}=14)$ & $92.9 \%$ & $7.14 \%$ & $0.00 \%$ \\
\hline Vancomycin $(n=14)$ & $92.9 \%$ & $0.00 \%$ & $7.14 \%$ \\
\hline Linezolid $(n=12)$ & $100.0 \%$ & $0.00 \%$ & $0.00 \%$ \\
\hline Colistin $(\mathrm{n}=18)$ & $50.0 \%$ & $50.00 \%$ & $0.00 \%$ \\
\hline Polymyxin B (n=9) & $100.0 \%$ & $0.00 \%$ & $0.00 \%$ \\
\hline Erythromycin $(\mathrm{n}=15)$ & $33.3 \%$ & $0.00 \%$ & $66.67 \%$ \\
\hline Cefaperazone Sulbactam $(n=6)$ & $83.3 \%$ & $16.67 \%$ & $0.00 \%$ \\
\hline Ceftazidime $(\mathrm{n}=4)$ & $100.0 \%$ & $0.00 \%$ & $0.00 \%$ \\
\hline Ofloxacin $(\mathrm{n}=6)$ & $66.7 \%$ & $0.00 \%$ & $33.33 \%$ \\
\hline Netilmicin $(n=4)$ & $100.0 \%$ & $0.00 \%$ & $0.00 \%$ \\
\hline Clindamycin $(n=4)$ & $75.0 \%$ & $0.00 \%$ & $25.00 \%$ \\
\hline Cloxacillin $(n=4)$ & $75.0 \%$ & $0.00 \%$ & $25.00 \%$ \\
\hline Chloramphenicol $(\mathrm{n}=2)$ & $100.0 \%$ & $0.00 \%$ & $0.00 \%$ \\
\hline Aztreonam $(n=3)$ & $66.7 \%$ & $0.00 \%$ & $33.33 \%$ \\
\hline Ceftriaxone $(\mathrm{n}=6)$ & $33.3 \%$ & $0.00 \%$ & $66.67 \%$ \\
\hline Tigecycline $(\mathrm{n}=1)$ & $100.0 \%$ & $0.00 \%$ & $0.00 \%$ \\
\hline
\end{tabular}

Table 6: Antibiotic sensitivity pattern of Enterococcus isolates in the study population

\begin{tabular}{|c|c|c|c|}
\hline \multirow[t]{2}{*}{ Antibiotic } & \multicolumn{3}{|c|}{ Enterococcus species } \\
\hline & Sensitive & Intermediate & Resistant \\
\hline Penicillin $(\mathrm{n}=129)$ & $74.4 \%$ & $0.00 \%$ & $25.58 \%$ \\
\hline Gentamicin $(n=264)$ & $34.1 \%$ & $50.00 \%$ & $15.91 \%$ \\
\hline Nitrofurantoin $(\mathrm{n}=106)$ & $80.2 \%$ & $7.55 \%$ & $12.26 \%$ \\
\hline Ampicillin $(\mathrm{n}=134)$ & $58.2 \%$ & $0.00 \%$ & $41.79 \%$ \\
\hline Linezolid $(\mathrm{n}=78)$ & $100.0 \%$ & $0.00 \%$ & $0.00 \%$ \\
\hline Teicoplanin $(\mathrm{n}=81)$ & $95.1 \%$ & $0.00 \%$ & $4.94 \%$ \\
\hline Vancomycin $(n=79)$ & $93.7 \%$ & $0.00 \%$ & $6.33 \%$ \\
\hline $\operatorname{Amikacin}(\mathrm{n}=35)$ & $97.1 \%$ & $0.00 \%$ & $2.86 \%$ \\
\hline Piperacillin-Tazobactam $(n=35)$ & $82.9 \%$ & $5.71 \%$ & $11.43 \%$ \\
\hline Gentamicin $(n=34)$ & $73.5 \%$ & $0.00 \%$ & $26.47 \%$ \\
\hline Norfloxacin $(n=89)$ & $27.0 \%$ & $4.49 \%$ & $68.54 \%$ \\
\hline Tetracycline $(n=26)$ & $61.5 \%$ & $0.00 \%$ & $38.46 \%$ \\
\hline Imipenem $(\mathrm{n}=18)$ & $88.9 \%$ & $0.00 \%$ & $11.11 \%$ \\
\hline Cefepime $(\mathrm{n}=35)$ & $40.0 \%$ & $5.71 \%$ & $54.29 \%$ \\
\hline Meropenem $(n=15)$ & $86.7 \%$ & $0.00 \%$ & $13.33 \%$ \\
\hline Cefotaxime $(n=32)$ & $37.5 \%$ & $0.00 \%$ & $62.50 \%$ \\
\hline Cotrimoxazole $(n=64)$ & $14.1 \%$ & $0.00 \%$ & $85.94 \%$ \\
\hline Tobramycin $(n=10)$ & $90.0 \%$ & $0.00 \%$ & $10.00 \%$ \\
\hline Cefuroxime $(n=32)$ & $21.9 \%$ & $0.00 \%$ & $78.13 \%$ \\
\hline Cefazolin $(n=62)$ & $8.1 \%$ & $0.00 \%$ & $91.94 \%$ \\
\hline Ceftazidime $(\mathrm{n}=3)$ & $100.0 \%$ & $0.00 \%$ & $0.00 \%$ \\
\hline Aztreonam $(\mathrm{n}=3)$ & $100.0 \%$ & $0.00 \%$ & $0.00 \%$ \\
\hline Ofloxacin $(n=4)$ & $75.0 \%$ & $0.00 \%$ & $25.00 \%$ \\
\hline Clindamycin $(n=4)$ & $25.0 \%$ & $0.00 \%$ & $75.00 \%$ \\
\hline Chloramphenicol $(\mathrm{n}=1)$ & $100.0 \%$ & $0.00 \%$ & $0.00 \%$ \\
\hline Colistin $(\mathrm{n}=2)$ & $50.0 \%$ & $50.00 \%$ & $0.00 \%$ \\
\hline Erythromycin $(\mathrm{n}=1)$ & $100.0 \%$ & $0.00 \%$ & $0.00 \%$ \\
\hline $\operatorname{Netilmicin}(\mathrm{n}=1)$ & $100.0 \%$ & $0.00 \%$ & $0.00 \%$ \\
\hline Polymyxin B (n=1) & $100.0 \%$ & $0.00 \%$ & $0.00 \%$ \\
\hline Ceftriaxone $(\mathrm{n}=1)$ & $0.0 \%$ & $0.00 \%$ & $100.00 \%$ \\
\hline Cloxacillin $(\mathrm{n}=1)$ & $0.0 \%$ & $0.00 \%$ & $100.00 \%$ \\
\hline
\end{tabular}




\section{Discussion}

The current study analysed 7683 prescriptions of children visiting our paediatric department with a complaint of fever. We also analysed the antibiotic sensitivity reports of children who had positive cultures. Fever in children less than five years old implies systemic inflammation in response to a viral, bacterial, parasitic or non-infectious aetiology $\mathrm{y}^{12}$.

Out of the 7683 children included in the study, $4973(64.7 \%)$ were below 5 years of age. Similar findings were seen in febrile children below 5 years of age by Kamath $\mathrm{K}$, et $a l^{9}$ and Monto $\mathrm{AS}^{10}$. As the age increases, the susceptibility to infection will reduce due to natural and acquired immunity by immunization to common pathogenic $\operatorname{organisms}^{11,12}$. B cell response and antibody production are critical for the development of protective immunity induced by most vaccines ${ }^{13}$. Christopher $\mathrm{A}$, et $a l^{14}$ conducted their study regarding bacteraemia on children below 5 years of age as infections preventable by vaccination are prevalent in that age group.

Male children constituted $56.8 \%$ of the study population. This may be a reflection of the sex distribution of children in the general population of the particular geographical area. This is similar to studies by Bronzan, RN, et al ${ }^{15}$ who reported $57 \%$ of males among Malawian febrile children and Christopher A, et $\mathrm{al}^{14}$ who reported $61.5 \%$ of boys.

In the current study, the culture positive infection rate was $18.8 \%$ (95\% CI $17.96 \%$ to $19.71 \%)$ among the study population. Similar high rates were seen in studies by Wasihun AG, et al ${ }^{16}$ (28\%) and Patel KK, et $a l^{17}(24.8 \%)$. In contrast to our study, Indian studies by Sujatha R, et $a l^{18}$ (14.8\%) and Vishalakshi $\mathrm{B}$, et $a l^{19}(14.8 \%)$ have shown lower culture positive infection rates. The reason for this wide disparity in positivity rates can be attributed to differences in techniques, antibiotic use or prevalence of effusions due to infective processes $^{17,20}$.

In our study, UTI was the commonest infection accounting for $9.9 \%$ children of all age groups. UTI is believed to be the second common community based and nosocomial infection worldwide ${ }^{21}$. This was followed by blood culture $(2.7 \%)$ and throat swab culture $(2 \%)$ positive cases. The proportion of UTI was slightly higher in girls (10.8\%), compared to boys $(9.2 \%)$. Similar findings were seen in a study by Taneja $\mathrm{N}$, et $a l^{22}$ where significant bacteriuria was found in 558 (28.3\%) children $^{22}$. Females are more prone to UTI after 6 months of age because of their shorter urethra. Children are also susceptible to blood stream infections and septicaemia as stated by Asindi A, et $a l^{23}$ due to their immature immune system.

Among children below 5 years of age, bacteraemia $(3.2 \%)$ was the next common infection whereas throat infection was the next common infection in the 5 to 10 year age group and wound infection in the over 10-year-old children. Similar results were reported by Le Doare K, et $a l^{24}$, where UTI was the commonest infection and infants of less than 12 weeks of age had a $17 \%$ probability of having SBI, $11 \%$ chance of having bacteraemia and $4 \%$ probability of meningitis.

Walsh $\mathrm{AL}$, et $a l^{25}$ in their study from Malawi documented bacteraemia among $17 \%$ of children in whom blood cultures were done. Common microbiological diagnoses in the study by Chheng, $\mathrm{K}$, et $a l^{6}$ were dengue $(16.2 \%)$, scrub typhus $(7.8 \%)$ and Japanese encephalitis (5.8\%). Such differences among studies may be due to differences in sampling criteria, the populations studied, their living conditions and the nutritional status.

In the current study, most bacteria isolated from blood were gram-negative. E. coli was the commonest organism grown in 5.4\% specimens followed by Enterococcus species in $1.8 \%$. Similar results were reported by Christopher A, et al ${ }^{14}$. Of the gram-negative bacteria, E. coli and Klebsiella pneumoniae were the common isolates. However, Prasad $\mathrm{N}$, et $a l^{5}$, in their systematic review on the aetiology of severe febrile illness found Plasmodium species as the most common organism. The other common infections reported were Salmonella species, S. pneumoniae, E.coli, mycobacterium, Rickettsial species and dengue virus. In contrast, in a study by Blomberg, B et $a l^{26}$, the common isolates were Streptococcus pneumoniae, Neisseria meningitides, Haemophilus influenzae type $b$ and Group A streptococci.

In the present study, E. coli has demonstrated maximum resistance to ampicillin, all generations of cephalosporins and macrolide group of antibiotics. A major proportion of Enterococcus species strains have shown resistance to cotrimoxazole, clindamycin, and various cephalosporins. Msaki BP, et $a l^{27}$ in a study in Tanzania found that most E. coli, Klebsiella pneumoniae and Salmonella species were resistant to gentamicin, chloramphenicol and sulfamethoxazole / trimethoprim. In a study done by Taneja $\mathrm{N}$, et $a l^{22}$ in vitro resistance for Enterobacteriaceae species including E. coli, Klebsiella, Enterobacter spp., and Citrobacter spp. was as follows: cefotaxime $75.5 \%$, cefoperazone $72.7 \%$, gentamicin $74.2 \%$, amoxicillin $32.7 \%$, nalidixic acid 94.4\%, norfloxacin $86 \%$, ciprofloxacin $\quad 79.6 \%, \quad$ trimethoprim- 
sulfamethoxazole $89 \%$, and nitrofurantoin $26.8 \%$. In vitro resistance for Enterococcus were as follows: ciprofloxacin $88 \%$, nitrofurantoin $32 \%$, amoxicillin $72 \%$ and vancomycin $12 \%$. This study shows that many bacterial strains are resistant to older conventional antibiotics, forcing the paediatricians to prescribe newer, highly toxic antimicrobial agents irrationally ${ }^{28}$.

\section{Conclusions}

Nearly one-fifth of children with febrile illness had culture-proven infections. The most common infection was UTI in all age groups and both genders. Among all the specimens, Escherichia coli was the commonest isolate followed by Enterococcus species. E. coli demonstrated maximum resistance to ampicillin, all generations of cephalosporins and macrolide group of antibiotics. Enterococcus species showed a major proportion of strains resistant to cotrimoxazole, clindamycin, and various cephalosporins.

\section{Acknowledgments}

We acknowledge the technical support in data entry, analysis and manuscript editing by "Evidencian Research Associates."

\section{References}

1. Chamberlain JM, Patel KM, Pollack MM. Association of emergency department care factors with admission and discharge decisions for paediatric patients. Journal of Pediatrics 2006; 149(5):644-9. https://doi.org/10.1016/j.jpeds.2006.05.04 7

PMid: 17095336

2. McCaig LF, Nawar EW. National Hospital Ambulatory Medical Care Survey: 2004 emergency department summary. Advance Data 2006; (372):1-29.

3. Baraff LJ, Bass JW, Fleisher GR, Klein JO, McCracken GH, Powell KR, et al. Practice guideline for the management of infants and children 0 to 36 months of age with fever without source. Annals of Emergency Medicine 1993; 22(7): 1198210.

https://doi.org/10.1016/S01960644(05)809 91-6

4. Lee GM, Fleisher GR, Harper MB. Management of febrile children in the age of the conjugate pneumococcal vaccine: a cost-effectiveness analysis. Pediatrics 2001; 108(4):835-44.

https://doi.org/10.1542/peds.108.4.835

PMid: 11581433
5. Prasad N, Murdoch DR, Reyburn H, Crump JA. Aetiology of severe febrile illness in low- and middle-income countries: A systematic review. PloS One 2015; 10(6): e0127962. https://doi.org/10.1371/journal.pone.0127 962

PMid: 26126200 PMCid: PMC4488327

6. Chheng K, Carter MJ, Emary K, Chanpheaktra N, Moore CE, Stoesser N, et al. A prospective study of the causes of febrile illness requiring hospitalization in children in Cambodia. PloS One 2013; 8(4): e60634.

https://doi.org/10.1371/journal.pone.0060 634

PMid: 23593267 PMCid: PMC3621876

7. Bachur RG, Harper MB. Predictive model for serious bacterial infections among infants younger than 3 months of age. Pediatrics 2001; 108(2): 311-6.

https://doi.org/10.1542/peds.108.2.311

PMid: 11483793

8. Harper MB. Update on the management of the febrile infant. Clinical Pediatric Emergency Medicine 2004; 5(1):5-12. https://doi.org/10.1016/j.cpem.2003.11.00 8

9. Kamath K, Feldman R, Sundar PR, Webb J. Infection and disease in a group of south Indian families. General morbidity patterns in families and family members. American Journal of Epidemiology 1969; 89(4): 375-83.

https://doi.org/10.1093/oxfordjournals.aje. a120951

PMid: 5778926

10. Monto AS. Studies of the community and family: acute respiratory illness and infection. Epidemiologic Reviews 1994; 16(2):351.

https://doi.org/10.1093/oxfordjournals.epir ev.a036158

PMid: 7713184 PMCid: PMC7108453

11. Baraff LJ, Bass JW, Fleisher GR, Klein JO, McCracken Jr GH, Powell KR, et al. Practice guideline for the management of infants and children 0 to 36 months of age with fever without source. Annals of Emergency Medicine 1993; 22(7):1198210. 
https://doi.org/10.1016/S01960644(05)809 91-6

12. Scott JAG, Berkley JA, Mwangi I, Ochola L, Uyoga S, Macharia A, et al. Relation between falciparum malaria and bacteraemia in Kenyan children: a population-based, case-control study and a longitudinal study. Lancet 2011; 378(9799): 1316-23. https://doi.org/10.1016/S01406736(11)608 $88-\mathrm{X}$

13. PrabhuDas M, Adkins B, Gans H, King C, Levy O, Ramilo O, et al. Challenges in infant immunity: implications for responses to infection and vaccines. Nature Immunology 2011; 12(3):189-94. https://doi.org/10.1038/ni0311-189

PMid: 21321588

14. Christopher A, Mshana SE, Kidenya BR, Hokororo A, Morona D. Bacteraemia and resistant gram-negative pathogens among under-fives in Tanzania. Italian Journal of Pediatrics 2013; 39:27.

https://doi.org/10.1186/1824-7288-39-27

PMid: 23657136 PMCid: PMC3665601

15. Bronzan RN, Taylor TE, Mwenechanya J, Tembo M, Kayira K, Bwanaisa L, et al. Bacteraemia in Malawian children with severe malaria: prevalence, aetiology, HIV coinfection, and outcome. Journal of Infectious Disease 2007; 195(6): 895-904. https://doi.org/10.1086/511437

PMid: 17299721

16. Wasihun AG, Wlekidan LN, Gebremariam SA, Dejene TA, Welderufael AL, Haile $\mathrm{TD}$, et al. Bacteriological profile and antimicrobial susceptibility patterns of blood culture isolates among febrile patients in Mekelle Hospital, Northern Ethiopia. Springer Plus 2015; 4(1):314. https://doi.org/10.1186/s40064-015-1471Z

17. Patel KK, Patel S, Sinha D. Bacteriological profile and antibiotic resistance pattern in blood stream infection in critical care units of a tertiary care hospital in central India. Blood 2016; 50:1.

18. Sujatha R, Nidhi $\mathrm{P}$, Arunagiri D, Narendran D. Bacteriological profile and antibiotic sensitivity pattern from various body fluids of patients attending Rama Medical College Hospital, Kanpur. International Journal of Advances in Case Reports 2015; 2(3):119-24.

19. Vishalakshi B, Hanumanthappa P, Krishna S. A study on aerobic bacteriological profile of sterile body fluids. International Journal of Current Microbiology and Applied Sciences 2016; 5(5):120-6. https://doi.org/10.20546/ijcmas.2016.505. 013

20. Ali J, Kebede Y. Frequency of isolation and antimicrobial susceptibility pattern of bacterial isolates from blood culture, Gondar University teaching hospital, Northwest Ethiopia. Ethiopian Medical Journal 2008; 46(2):155-61.

21. Marcus N, Ashkenazi S, Yaari A, Samra Z, Livni G. Non-Escherichia coli versus Escherichia coli community-acquired urinary tract infections in children hospitalized in a tertiary center: relative frequency, risk factors, antimicrobial resistance and outcome. Pediatric Infectious Disease Journal 2005; 24(7):581-5.

https://doi.org/10.1097/01.inf.0000168743 .57286 .13

PMid: 15998996

22. Taneja N, Chatterjee SS, Singh M, Singh $\mathrm{S}$, Sharma M. Pediatric urinary tract infections in a tertiary care centre from North India. Indian Journal of Medical Research 2010; 131(1):101-5.

23. Asindi A, Ibia E, Udo J. Mortality pattern among Nigerian children in the 1980s. Journal of Tropical Medicine and Hygiene 1991; 94(3):152-5.

24. Le Doare K, Nichols AL, Payne H, Wells R, Navidnia S, Appleby G, et al. Very low rates of culture-confirmed invasive bacterial infections in a prospective 3-year population-based surveillance in Southwest London. Archives of Disease in Childhood 2014; 99(6): 526-31.

https://doi.org/10.1136/archdischild-2013305565

PMid: 24554055

25. Walsh AL, Phiri AJ, Graham SM, Molyneux EM, Molyneux ME. Bacteremia in febrile Malawian children: clinical and microbiologic features. 
Pediatric Infectious Disease Journal 2000; 19(4): 312-8

https://doi.org/10.1097/000064542000040 00-00010

PMid: 10783021

26. Blomberg B, Manji KP, Urassa WK, Tamim BS, Mwakagile DS, Jureen R, et al. Antimicrobial resistance predicts death in Tanzanian children with bloodstream infections: a prospective cohort study. BMC Infectious Disease 2007; 7(1):43. https://doi.org/10.1186/1471-2334-7-43 PMid: 17519011 PMCid: PMC1891109

27. Msaki BP, Mshana SE, Hokororo A, Mazigo HD, Morona D. Prevalence and predictors of urinary tract infection and severe malaria among febrile children attending Makongoro health centre in Mwanza city, North-Western Tanzania. Archives of Public Health 2012; 70(1):4. https://doi.org/10.1186/0778-7367-70-4 PMid: 22958592 PMCid: PMC3415110

28. Cliff-Eribo KO, Sammons H, Choonara I. Systematic review of paediatric studies of adverse drug reactions from pharmacovigilance databases. Expert Opinion on Drug Safety 2016; 15(10): 1321-8.

https://doi.org/10.1080/14740338.2016.12 21921

PMid: 27501085 